\title{
Making Climate Change Policy Work at the Local Level: Capacity-Building for Decentralized Policy Making in Japan Yasuo Takao*
}

\begin{abstract}
This study will examine the state of local capacity building for local climate adaptation in Japan. Climate mitigation needs to be led by both global strategies and national mandates in an integrated way, but climate change impacts are manifested locally and adaptive capacity is determined by local conditions. The article first lays out the basic components of local capacity for decentralized policy making and assesses the current local capacity in view of Japan's climate policy. The bulk of data employed in the study is derived from existing up-to-date government databases. It found that only the largest municipalities as well as prefectures have governing capacities to develop a comprehensive approach to climate adaptation, while mediumsized municipalities have a potential to take a participatory approach to climate policy. It argues that some pioneering localities realize their potentials to take initiatives under political leadership but most localities act in a piecemeal fashion according to clear national-level guidance on climate change.
\end{abstract}

KEYWORDS: Japan, local government, climate change, decentralization, local capacity building

DOI: http:/ /dx.doi.org/10.5509/2012854767

\section{Introduction}

T $\mathrm{n}$ the 1970s, Japanese local government was known for its progressive policy of industrial pollution control, with other Organization of Economic Co-operation and Development (OECD) countries emulating Japan's local environmental innovations. In the late 1960s, when industrial

* I gratefully acknowledge the extensive and constructive comments of anonymous reviewers and the assistance of Susan Takao. 
pollution fuelled local environmental activism in Japan, it became apparent that the centralized image of Japan would require a closer examination. Some scholars suggested that Japan was less centralized than most academic Japanspecialists had initially thought and its local government system had much more discretion than they had expected. ${ }^{1}$ In the absence of national legislation, Japanese local governments, pressured at the time by developing movements of residents in their pollution-affected localities, exercised their discretionary power for policy innovations. ${ }^{2}$ They played a critical role in policy diffusion to the national level to tackle pollution problems.

However, the local policy environment appears to have significantly changed over the last two decades. Japan's local environmental responses have shifted from predominantly contentious activities in domestic politics to a far more complex process that involves both local coordination with national policy and local adaptations to global environmental strategies. On the global level, the importance of local policy making can be traced back to ideas incorporated in Agenda 21 (an action plan of sustainable development adopted at the 1992 Earth Summit), with emphasis on the local level of participation, the layer of government closest to the people. ${ }^{3}$ Ever since the acknowledgement of a vital community role in the implementation of global strategies for sustainable development within the Agenda 21 framework, the position of local communities has been further promoted and strengthened by a series of decision making at both the national and international levels. In 1993 the International Council for Local Environmental Initiatives (ICLEI) launched the notion of Local Agenda 21, a participatory, multi-sectoral process, in which local participants voluntarily create long-term, strategic action plans and implement them to achieve sustainability by integrating environmental, social and economic priorities. ${ }^{4}$ Article 34 of Japan's Basic Environmental Law, which was enacted in the same year, acknowledged the role of local governments as the subjects of international environmental cooperation.

The local level of participation in climate change policy is increasingly expected for two basic grounds: the need for locally specific responses to global strategies and the need for a decentralized form of redistributing

1 Richard Samuels, The Politics of Regional Policy in Japan (Princeton: Princeton University Press, 1983); Steven Reed, Japanese Prefectures and Policy Making (Pittsburgh: University of Pittsburgh Press, 1986).

Michio Muramatsu, "The Impact of Economic Growth Policies on Local Politics in Japan," Asian Survey 15, no. 9 (September 1975): 799-816; Kurt Steiner, Ellis Krauss and Scott Flanagan, eds., Political Opposition and Local Politics in Japan (Princeton: Princeton University Press, 1980); Steven Reed, "Environmental Politics: Some Reflections Based on the Japanese Case," Comparative Politics 13, no. 3 (April 1981): 253-69.

United Nations Conference on Environment and Development, Agenda 21. Rio de Janeiro: UNCED, 3-14 June 1992; available from http://www.un.org/esa/sustdev/documents/agenda21/ english/adenda21 toc.htm, last accessed 3 December 2009.

International Council for Local Environmental Initiatives, The Local Agenda 21 Initiative: ICLEI Guidelines for Local Agenda 21 (Freiburg: ICLEI, 1993). 
global environmental functions. ${ }^{5}$ Global strategies for environmental risk reduction require local action while local environmental problem solving demands global coordination. ${ }^{6}$ From the viewpoint of local policy making, the central issue boils down to local authorities' willingness and capability of contributing to problem solving to cater for both locally specific needs and global strategies. Yet the key problem for local capacity building is an inadequate delegation of power to lower levels of government. ${ }^{7}$ Firstly, in many countries, local governments do not have the fiscal capacity to include funding requirements into their environmental programs. Second, they often lack sufficient jurisdiction over the implementation of environmental policies. Equally important, there exist two fundamental blockages within local administrations: lack of information and expertise and incapability of interdepartmental coordination. ${ }^{8}$ From the viewpoint of multi-level governance, action at local scales cannot be effective in isolation from components of the institutional frameworks at national scales. ${ }^{9}$ The reputation of Japanese local governments for being innovative in the 1970s is well worth inquiry into their adaptation to the new policy environment. The case of Japan's efforts at local capacity building offers an opportunity to examine how to make climate change policy work at the local level.

\section{Analytical Frameworks}

There has been a great deal in the literature on the advantages of decentralized public policy. Earlier research on decentralized decision making for service delivery found numerous benefits. First, as environmental problems are often location-specific, differences in geographical areas can be effectively dealt with in decentralized decision making..$^{10}$ Second,

5 Michael Shuman, Toward a Global Village: International Community Development Initiatives (London: Pluto, 1994); Lara Green, Chris Game and Simon Delay, Why Should My Local Authorities be Involved in an Overseas Project? (Birmingham: Birmingham University, 2005).

6 Hugh Dyer, "Environmental Ethics and International Relations," Paradigms 8, no. 1 (Summer 1994): 58-77; Karen Litfin, "Advocacy Coalitions along the Domestic-Foreign Frontier: Globalization and Canadian Climate Change Policy,” Policy Studies Journal 28, no. 1 (2000): 236-52.

7 Harriet Bulkeley and Heike Schroeder, "Governing Climate Change Post-2012: The Role of Global Cities Case-Study - Los Angeles,” Working Paper 122, Wallingford, UK, Tyndall Center for Climate Change Research, 2008; Kristine Kern and Alber Gotelind, "Governing Climate Change in Cities: Modes of Urban Climate Governance in Multi-Level Systems," OECD Conference Proceedings, Paris, OECD, 2009.

8 Claudia Holgate, "Factors and Actors in Climate Change Mitigation: A Tale of Two South African Cities," Local Environment 12, no. 5 (2007): 471-84; Barry Rabe, "Governing the Climate from Sacramento," in Unlocking the Power of Networks, eds., Stephen Goldsmith and Donald Kettl (Washington, DC: Brookings Institution Press, 2009), 34-61.

9 Thomas Dietz, Elinor Ostrom and Paul Stern, "The Struggle to Govern the Commons," Science 302 (2003): 1907-12; Liesbet Hooghe and Gary Marks, "Unravelling the Central State, but How? Types of Multi-Level Governance,” American Political Science Review 97, no. 2 (May 2003): 233-43.

10 Thomas H. Tietenberg, "On the Efficient Spatial Allocation of Air Pollution Control Responsibility," in Regional Environmental Policy: The Economic Issues, eds. Horst Siebert, Ingo Walker and Klaus Zimmermann (New York: New York University Press, 1979), 79-83; Horst Siebert, Economics of the Environment: Theory and Policy (Berlin and Heidelberg: Springer Verlag, 1992). 
decentralized units are positioned well to make the processing of interest articulation and aggregation easier since public preferences are available in the immediate environment ${ }^{11}$ or as voters move from one community to another to satisfy their service preferences. ${ }^{12}$ Third, the specific operations of decentralization provide the chances for enhancing the visibility of service performance and the traceability of responsibility, and thus increase accountability to stakeholders. ${ }^{13}$ Lastly, subject to inter-jurisdictional competition, decentralized control over the economy responds to citizens' needs as well as prevents the central government from interfering with markets. $^{14}$

What government level of policy making then is better suited for environmental issues? The impact of decentralized governance on environmental quality has been documented in the empirical literature but evidence reported in a number of studies shows mixed results. Some studies provide evidence that devolving authority did result in inefficient regulatory competition or "a race to the bottom" that would lower environmental quality to compete for capital. ${ }^{15}$ They also report evidence of "free riding" by subnational governments that chose lower environmental standards than the national government would choose, to export the environmental costs to their neighbours. ${ }^{16}$ Others argue that there is no evidence of such destructive regulatory competition and many subnational governments do not even exercise their discretion in favour of lower environmental standards. ${ }^{17}$ These results appear to be mixed yet a list of preconditions necessary for decentralized environmental policies to be efficient would explain these apparently mixed results in a more consistent way. For decentralization to realize the potential benefits of efficiency and equitability, the literature suggests several capacity-based preconditions: intergovernmental

11 Wallace E. Oates, Fiscal Federalism (New York: Harcourt Brace and Jovanovich, 1972).

12 Charles Tiebout, "A Pure Theory of Local Expenditures," The Journal of Political Economy 64, no. 5 (October 1956): 416-24.

13 George Peterson, Decentralization in Latin America: Learning through Experience (Washington, DC: World Bank, 1997).

14 Barry R. Weingast, "The Economic Role of Political Institutions: Market-preserving Federalism and Economic Development," Journal of Law, Economics and Organization 11, no. 1 (Spring 1995): 1-31; Ronald McKinnon, "The Logic of Market-preserving Federalism," Virginia Law Review 83, no. 7 (October 1997): 1573-80.

15 Per G. Fredriksson and Daniel Millimet, "Strategic Interaction and the Determination of Environmental Policy across US states," Journal of Urban Economics 51, no. 1 (January 2002): 101-22; Arik Levinson, "Environmental Regulatory Competition: A Status Report and Some New Evidence," National Tax Journal 56, no. 1 (March 2003): 91-106.

16 Eric Helland and Andrew Whitford, "Pollution Incidence and Political Jurisdiction: Evidence from the TRI," Journal of Environmental Economics and Management 46, no. 3 (November 2003): 403-24; Hilary Sigman, "Transboundary Spillovers and Decentralization of Environmental Policies," Journal of Environmental Economics and Management 50, no. 1 (July 2005): 82-101.

17 John List and Shelby Gerking, "Regulatory Federalism and Environmental Protection in the Unites States," Journal of Regional Science 40, no. 3 (August 2000): 453-71; Wallace E. Oates, "A Reconsideration of Environmental Federalism," in Recent Advances in Environmental Economics, eds., John List and Aart de Zeeuw (Cheltenham, UK: Edward Elgar Publisher, 2002), 1-32. 
cooperation at the sub-national level without centralized intervention; ${ }^{18}$ fiscal autonomy and discretion; ${ }^{19}$ administrative capacity; ${ }^{20}$ democratic political institutions ${ }^{21}$ responsive local officials $;{ }^{22}$ and civic engagement. ${ }^{23}$

In this article, while drawing on the above literature, as table 1 shows, local capacity necessary for policy decentralization to be effective is examined from two viewpoints: Performance Evaluations and Citizens' Orientations. The evaluations of local government performance draw on two fundamental causal paths: governmental procedures (the quality of representational links between citizens and local government: accountability and attentiveness) and governmental performance (the evaluations of policy making and implementation activities of local government: efficiency and fairness). The orientations of citizens are linked into two causal paths: the individual's subjective makeup of political involvement (personal orientations and expectations) and the interpersonal makeup of social relations relevant to collective action (collective orientations and expectations among citizens).

The quality of governmental procedures requires two basic conditions: accountability mechanisms (referring to a mechanism that allows wide, effective participation in light of the governmental ability to provide access and to hold officials accountable) and officials' attentiveness (officials' actual attentiveness to what the people think). ${ }^{24}$ The equality of accountability can be observed by assessing the institutional mechanisms of linkage process that relates the government to the citizenry. These include climate-changespecific ones such as Local Agenda 21, action plans and environmental impact assessments. The accountability mechanisms are crucial structures of legitimate government, but they are effective to the extent that officials

18 Paul Shapiro and Jeffrey Petchey, "The Welfare Economics of Environmental Regulatory: Two Parables on State vs. Federal Control," in The Economic Theory of Environmental Policy in a Federalism, New Horizons in Environmental Economics, eds., John B. Braden and Stef Proost (Cheltenham, UK: Edward Elgar Publisher, 1997), 122-46.

19 Paul Seabright, "Accountability and Decentralization in Government: An Incomplete Contracts Model,” European Economic Review 40, no. 1 (January 1996): 61-89.

20 Ariel Fiszbien, “The Emergence of Local Capacity: Lessons from Colombia,” World Development 25, no. 7 (July 1997): 1029-43; Anne M. Larson, "Natural Resources and Decentralization in Nicaragua: Are Local Governments up to the Job?" World Development 30, no. 1 (January 2002): 17-31; Asian Development Bank, Capacity Building to Support Decentralization in Indonesia (Manila: ADB, 2005).

${ }_{21}$ Richard Crook and James Manor, Democracy and Decentralization in Southeast Asia and West Africa; (Cambridge: Cambridge University Press, 1998); Krister Andersson and Frank van Laerhoven, "From Local Strongman to Facilitator: Institutional Incentives for Participatory Municipal Governance in Latin America," Comparative Political Studies 40, no. 9 (September 2007): 1085-111.

22 Jonathan Rodden, "Comparative Federalism and Decentralization: On Meaning and Measurement,” Comparative Politics 36, no. 4 (July 2004): 481-500.

23 Robert D. Putnam, Making Democracy Work: Civic Traditions in Modern Italy (Princeton: Princeton University Press, 1993); Edward P. Weber, Pluralism by the Rules: Conflict and Cooperation in Environmental Regulation (Washington, DC: Georgetown University Press, 1998); Paul Selman, "Social Capital, Sustainability and Environmental Planning," Planning Theory and Practice 2, no. 1 (April 2001): 13-30.

24 The accountability mechanism for monitoring provides incentives for the attentiveness of officials to constituents. But it is procedurally operational only to the extent that officials recognize and act on the incentives. 
acknowledge the incentive structures designed to increase their attentiveness. Evidence of officials' attentiveness can be sought in the incentive structures of climate change, such as environmental performance disclosure and personnel management.

The quality of governmental performance is tapped by two conditions: officials' efficiency (officials' capacity to accomplish their tasks without undue waste of time or resources) and fairness of government outputs (fairness of costsharing in local government's outputs). These two conditions address procedural efficiency and overall fairness respectively. Key indicators for such efficiency in climate policy, as discussed later, are chief executives' leadership, administrative ability and fiscal capacity. In this policy area, fairness involves mitigation cost-sharing rather than potential benefits of environmental risk reduction, since these benefits are both non-excludable and non-rival. As indicated in this study, environmental impact assessment at early stages and citizen involvement are a minimal condition for overall fairness.

Table 1

Local Capacity for Decentralized Policy Making

\begin{tabular}{|c|c|c|c|}
\hline & Dimension & Definition & Empirical indicators \\
\hline \multirow[t]{2}{*}{$\begin{array}{l}\text { Governmental } \\
\text { procedures }\end{array}$} & $\begin{array}{l}\text { Accountability } \\
\text { mechanisms }\end{array}$ & $\begin{array}{l}\text { Access to hold } \\
\text { officials } \\
\text { accountable }\end{array}$ & $\begin{array}{l}\text { Institutions that press } \\
\text { officials to take account } \\
\text { of citizens' views }\end{array}$ \\
\hline & $\begin{array}{l}\text { Officials' } \\
\text { attentiveness }\end{array}$ & $\begin{array}{l}\text { Attentiveness } \\
\text { to public } \\
\text { preference }\end{array}$ & $\begin{array}{l}\text { Facts if officials actually } \\
\text { take proper accounts } \\
\text { of citizens' views }\end{array}$ \\
\hline \multirow[t]{2}{*}{$\begin{array}{l}\text { Governmental } \\
\text { performance }\end{array}$} & $\begin{array}{l}\text { Officials' } \\
\text { efficiency }\end{array}$ & $\begin{array}{l}\text { Ability to } \\
\text { perform tasks } \\
\text { efficiently }\end{array}$ & $\begin{array}{l}\text { Efficiency of leadership } \\
\text { and administration }\end{array}$ \\
\hline & $\begin{array}{l}\text { Fairness of } \\
\text { government } \\
\text { outputs }\end{array}$ & $\begin{array}{l}\text { Fairness of } \\
\text { cost-sharing }\end{array}$ & $\begin{array}{l}\text { Wide, effective } \\
\text { participation }\end{array}$ \\
\hline \multirow[t]{3}{*}{$\begin{array}{l}\text { Citizens' } \\
\text { orientations }\end{array}$} & $\begin{array}{l}\text { Political } \\
\text { interest }\end{array}$ & $\begin{array}{l}\text { Responsibility } \\
\text { for citizen } \\
\text { participation }\end{array}$ & Interest in politics \\
\hline & $\begin{array}{l}\text { Political } \\
\text { efficacy }\end{array}$ & $\begin{array}{l}\text { Prospect for } \\
\text { successful } \\
\text { citizen } \\
\text { participation }\end{array}$ & $\begin{array}{l}\text { Perception of } \\
\text { government institutions }\end{array}$ \\
\hline & $\begin{array}{l}\text { Interpersonal } \\
\text { trust }\end{array}$ & $\begin{array}{l}\text { Shared } \\
\text { expectations } \\
\text { among citizens }\end{array}$ & Trust in people \\
\hline
\end{tabular}


The subjective makeup of political involvement is shaped by two prominent conditions: political interest (personal feelings of responsibility for citizen participation) and political efficacy (personal feelings about the prospect for successful citizen participation) ${ }^{25}$ In addition to predispositions, social networks provide a potential for a higher level of political participation. The interpersonal makeup of social relations is accounted for by a primary condition: interpersonal trust (shared expectations situated in relationships between citizens). ${ }^{26}$ The subjective and interpersonal makeup can be observed by citizens' perceptions.

The following section will assess the Japanese local capacity to meet locally specific conditions as well as national policy frameworks and international agreements while drawing on the analytical framework of those key components.

\section{Political Involvement}

\section{Political interest}

Today Japanese public concerns about climate change are particularly high: a 2007 government survey found that 92.3 percent of the public expressed levels of concern ranging from "very" or "modest." ${ }^{27}$ If major trends in public opinion are paralleled by coverage in the mass media, then a near explosion of climate change coverage that began in 1989 indicates a sudden upward trend in public awareness about climate change. Newspaper articles with key words, chikyū kankyō (global environment) and/or chikyū ondanka (global warming), increased rapidly in number from 7 in 1986 through 1,430 in 1989 to 2,633 in 1992 when the Earth Summit took place. ${ }^{28}$ Yet, a number of studies found that, despite the public awareness, societal actors were yet to be mobilized to influence the policy-making process. ${ }^{29}$ In the 1960 s and early 1970s, the Japanese politics of industrial pollution involved the costs of industrial poisoning, and the visible costs of human life itself. The

25 The indices for citizens' orientations are adopted from the civic culture literature: Gabriel A. Almond and Sidney Verba, The Civic Culture (Princeton: Princeton University Press, 1963), chapters 10, 11 and Sidney Verba and Norman Nie, Participation in America: Political Democracy and Social Equality (New York: Harper \& Row, 1972), chapters 9-13.

26 The index for interpersonal trust is adopted from the social capital literature: Robert D. Putnam, Making Democracy Work: Civic Traditions in Modern Italy (Princeton: Princeton University Press, 1993), chapter 6.

${ }_{27}$ Japan, Cabinet Office, Chikyū Ondanka Taisaku ni kansuru Yoron Chōsa [Public opinion survey on global warming countermeasures]; available from http://www8.cao.go.jp/survey/h19/h19globalwarming/index.html, last accessed 12 November 2009.

${ }_{28}$ The figures are calculated by the author from two major national newspapers (i.e., through on-line indexing services provided by digital news archives): Asahi Shinbun and Yomiuri Shinbun.

29 Miyauchi Taisuke, "Kankyō Jichi no Shikumizukuri" [Environmental self-governance and its organization], Kankyō Shakaigaku Kenkyū [Journal of Environmental Sociology] 7 (2001): 56-71; Wada Takeshi, "Nijūisseiki no Chikyū Kankyō to Shakai Hatten" [The Earth's environment for the twentyfirst century and social development], Yuibutsuron to Gendai [Materialism and Today] 29 (May 2002): 2-15; Hasegawa, Kōichi, Kankyō Undō to Atarashii Kokyōken [Environmental movements and new public space] (Tokyo: Yūhikaku, 2003). 
immediate causes of industrial pollution, unlike non-industrial pollution, were easy to identify and confront. In contrast, in the 1990s the objectives of Japan's environmental policy moved away from one-dimensional pollution control toward a sustainable society and environment. The general public had limited capacity to confront diffused, "no-point sources" of pressures on the environment. The low visibility of long-term mitigation benefits that the general public is supposed to receive tends to prevent the general public from citizen participation. ${ }^{30}$ In this context, the importance of environmental education has already been identified by local authorities and a range of climate change education in the curriculum of schools has been implemented across the nation. ${ }^{31}$

\section{Political efficacy}

According to a survey by the company NTT Data, the lower the level of government, the higher the citizens' expectations of representation. The survey asked who "should decide on important issues of municipal governance." A high of 88 percent of respondents answered, "Residents should directly participate in decision-making," in sharp contrast to only 11 percent answering, "Publicly elected representatives should decide." Although a mere 8 percent had experienced direct participation in such decision making at some level, 37 percent had not yet had a chance to participate but wished to do so when the opportunity arose. ${ }^{32}$ This is a significant percentage of potentially proactive citizens. It is clear that there is plenty of room for the incorporation of local environmental policy making into inclusive democracy building.

As the same survey shows that 47 percent felt their views to be represented at the municipal level while only 8 percent felt so at the national level, Japanese local governments are relatively trusted institutions. Indeed, positions as local civil servants are deemed to be one of the most desirable jobs among university graduates. ${ }^{33}$ Yet Japanese local governments are now

30 Hasegawa, Kankyō Undō to Atarashii Kokyōken; Hiraoka Shun'ichi and Wada Takeshi, "Chihō Jichitai ni okeru Shiminsankagata no Chikyū Ondanka Taisaku o Suishinsuru Shikumi to Shakaiteki Haikei" [Political system and social background for the promotion of climate mitigation through citizens participation in local government], Ritsumeikan Sangyōshakai Ronshu [Ritsumeikan University Industrial Society Papers] 41, no. 2 (September 2005): 49.

${ }_{31}$ Wada Takeshi and Taura Kenrō, Shimin Chiiki ga Susumeru Chikyū Ondanka Bōshi [Climate change countermeasures by citizens and community] (Kyoto: Gakugei Shuppan, 2007), 132-52; Kitagawa Hideki (ex-Kyoto Prefecture official of Bureau of the Environment), interview by author, 13 May 2010, Kyoto; Taura, interview by author, 13 May 2010, Kyoto; Japan Center for Climate Change Actions, "Chiiki no Dōkō" [Regional Trends]; available from http://www.jccca.org/trend_region/, last accessed 1 November 2011.

32 In August 2001 NTT Data conducted this survey on 1,000 people aged 20 and over who resided in ten cities in the capital region. See NTT Data, "Denshi Seifu to Minshushugi ni kansuru Shutoken Shimin Chōsa" [Investigation report on citizens in the capital region for e-government and democracy], December 2001.

33 Nikkei Human Resources, Nikkei Navi, available from http://job.nikkei.co.jp, last accessed 15 June 2006. 
facing the challenge of meeting the needs of multi-sectoral climate action. The communication processes between local administration and citizens are expected to enhance the transparency and social equity of cost-sharing for climate action and thus increase personal feelings about the prospect for successful citizen participation.

Over the past decade, some form of direct citizen participation (shimin sanka) in local policy making has become common among municipalities. The 1993 enactment of the national Basic Environmental Law encouraged local governments to prepare their own environmental basic bylaws and plans, and the national grant program paid 50 percent of actual costs for preparing such plans, in anticipation of compliance with the senshinsei (advancement) of planning process (i.e., citizens' participatory role in the process).$^{34}$ This triggered abrupt increases in the nationally defined inclusion of citizens for preparing local environmental plans. As of 2010, Basic Environmental Bylaws had been enacted in 55.2 percent of 1,358 local governments and Basic Environmental Plans had been prepared by 52.4 percent of those local governments. ${ }^{35}$ In preparing their basic environmental plans, these local governments normally created a sole participatory mechanism, advisory environmental councils (shingikai), whose membership composition was similar to the national councils representing business, interest groups and academics rather than concerned ordinary citizens. ${ }^{36}$ The national top-down promotion had failed to provide much in the way of substantial citizen participation in local environmental policy making. Nonetheless, it is important to note that there are two pioneering cases, Toyonaka City ${ }^{37}$ and Hino City, ${ }^{38}$ reported as the purely, indeed only faithfully, citizen-led environmental policy making: a group of openly invited citizens in both cities conducted data collection, site investigation, measurement, and assessment and local assemblies adopted their draft plan in March 1999 and September 1999 respectively. Otherwise, substantial citizen participation was reported in a dozen cases of collaboration between citizens and local administration for local environmental planning. On balance, therefore, the environmental policy-making structure, meant to enhance an individual's sense that they can make a difference-their sense of political efficacy-is at an early embryonic stage.

34 Takahashi Hideyuki, "Jichitai Kankyō Kihon Keikaku no Genjō to Kadai” [The state and problems of local basic environmental plans], Kikan Gyōsei Kanri Kenkyū [Administrative Management Quarterly] 89 (March 2000): 20-21.

35 In January-March 2011, the Ministry of the Environment conducted this survey on all 1,797 local governments. See Ministry of the Environment, "Kankyō Kihon Keikaku ni Kakawaru Chihō Kōkyō Dantai Ankēto Chōsa” [Survey on basic environmental plans by local government], September 2011.

36 Takahashi, “Jichitai Kankyō Kihon Keikaku no Genjō to Kadai,” 21-22.

37 Kawasaki Kenji, "Aratana Dankai o Mukaeta Shimin Sanka” [An emerging new phase for citizen participation], Chihō Zaimu [Local Finance] 568 (September 2001): 276-77.

38 Kayashima Makoto, "Hinoshi okeru Kankyō Kihon Keiaku Sakutei" [Formulation of Hino City's Basic Environmental Plan], Tokyo no Jichi [Autonomy Tokyo] 18, no. 33 (June 1999): 18-25. 


\section{Interpersonal trust}

A series of nationwide surveys, although providing limited measurement indexes used to compare different localities in Japan, indicate that the positive relationship is present between social trust and participation. ${ }^{39}$ The 2005 Cabinet Office survey asked questions concerning the degree of trust in people on a scale of 1 (not trustworthy) to 9 (most trustworthy): 25.6 percent of "designated cities," with a population at least 500,000, indicated a level 6 or more, compared with cities/towns at 27.8 percent and villages 28.3 percent, while finding that the rate of regular participation in voluntary work was 8.7 percent in designated cities, 13.8 percent in cities/towns, and 18.2 percent in villages. The levels of both social trust and participation were relatively low in major cities such as Tokyo and Osaka while they were higher in rural localities. All in all, the higher the level of social trust the greater the involvement in voluntary work. It is important to note here that since the introduction of the Nonprofit Organization Law in 1998, the number of legally registered voluntary organizations rose rapidly to over 45,000 in March 2012. The rise of organized voluntary activity in major and mediumsized cities seems to have produced a new type of social capital, bringing different groups together for more inclusive social networks. ${ }^{40}$ The role of these organizations as mobilization agencies is yet to be examined.

\section{Governmental Procedures}

\section{Accountability mechanisms}

Making climate change policy work requires the informed participation of all stakeholders. Probably the most notable development of information disclosure in environmental policy is the introduction of evaluation and announcement programs regarding GHG (greenhouse gas) emissions reduction. In these programs, large GHG-emitting business facilities are required to submit a GHG emissions reduction plan. This plan is evaluated and the results are officially announced. As of April 2010, 36 percent (17) of 47 prefectures and 32 percent (6) of 19 designated cities were implementing such measures at some level. ${ }^{41}$ In Kyoto City, since 2005, 148 designated facilities have been required to submit their $\mathrm{CO}_{2}$ emissions reduction plans and outcome reports and these documents have been released to the public. ${ }^{42}$ In a similar way, the Tokyo metropolitan government designated 1,332

\footnotetext{
39 See, for example, Japan, Cabinet Office, Sōsharu Kyapitaru [Social capital], 2002 ed., survey report, June 2003; Japan, Cabinet Office, Community Regeneration and Social Capital, survey report, August 2005; NHK Broadcasting Culture Research Institute, Zenkoku Kenmin Ishiki Chosa [An attitude survey on prefectural inhabitants], 1978 and 1996.

40 Japan, Cabinet Office, Sōsharu Kyapitaru, p. 5.

41 Material provided by the Bureau of the Environment, Tokyo Metropolitan Government.

42 Imai Kunimitsu (Kyoto City Department Chief of Countermeasure Planning for Global Warming), interview by author, 18 May 2010, Kyoto, Japan.
} 
facilities in 2005 and officially announced the evaluation of their submitted five-year reduction plans. The experience of information disclosure under this system facilitated the consultative process in an effective way for the 2010 introduction of Tokyo's cap and trade system targeting large $\mathrm{CO}_{2}$-emitting business establishments. ${ }^{43}$

To make informed citizens active, there are specific modes of participatory accountability mechanisms available at the local level of Japan's climate change policy: Local Agenda 21; local Climate Change Action; and local EIA (environmental impact assessments).

\section{Local Agenda 21}

In January 1993, for the first time in Japan, Kanagawa prefecture made a Local Agenda 21 program, and by March 2003, all remaining 46 prefectures and 330 municipalities had followed suit. ${ }^{44}$ In Japan, the policy area of Local Agenda 21 came under the jurisdiction of the Environmental Agency (reorganized as the Ministry of the Environment in 2001), which had supervised the prefectural adoption (of Local Agenda 21) and the municipal adoption via prefectural environmental departments. This narrow, vertical tutelage was incapable of effective coordination among environmental and non-environmental policy areas. Most municipalities had already had "longterm comprehensive plans" (sōgō keikaku) at the highest level of local governmental plans, as defined in Local Autonomy Law (Article 2-4). Local government officials tended to see Local Agenda 21 as one of various administration activities, not as a plan to integrate these activities. Unlike the ICLEI definition of Local Agenda 21, Japan's Environmental Agency saw Local Agenda 21 as a final product of community plans rather than as an interactive process itself between stakeholders for increasing local accountability in making communities more sustainable. ${ }^{45}$ Local Agenda 21 programs in Japan were consequently reported to indicate peculiar patterns: over 70 percent of these Local Agenda 21s were regarded as a mere administration plan rather than a societal, voluntary process of local community consultation ${ }^{46}$ and almost all were aimed at a narrowly defined environmental issue rather than at a broadly conceived inter-issue-linkage of sustainability, except for a few localities such as Kyoto and Minamata Cities

43 Chiba Toshiko (Tokyo Metropolitan Department Chief of Global Warming Countermeasures), interview by author, 20 May 2010, Tokyo, Japan; Ōno Teruyuki, "Tokyo wa mou Hajimete Imasu" [Tokyo has already started!] Gaikō Fōramu [Diplomacy Forum], 260 (March 2010): 42-45.

44 Ministry of the Environment, Press Release, 13 May 2003.

45 See Environmental Agency, "Rōkaruajenda 21 Sakutei Gaido" [Guidelines for formulating Local Agenda 21], June 1995.

${ }_{46}$ Ministry of the Environment, "Rōkaruagenda 21 no Sakutei Jōkyōtou Chōsa Kekka nit suite" [Results on the investigation of the state of Local Agenda 21 programming], March 2003; available from http:/ / www.env.go.jp/press/press.php?serial=4101, last accessed 3 December 3 2009; Nakaguchi Takahiro, "Nihon no Rōkaruagenda to Rōkaruakushon no Genjō to Kadai" [The state and problem of Japan's Local Agenda 21 and local action] Architectural Institute of Japan Seminar, August 2002. 
and Nirayama Town, where the integration of planning and action across economic, social and environmental spheres was sought. ${ }^{47}$

It was reported that, at the first phase of planning and policy making, as of March 2003, 40 percent of Local Agenda 21 programs at the prefectural level and 67 percent at the municipal level provided citizens with direct access to decision making. ${ }^{48}$ Nonetheless, a very few cases, such as Hikone, Joetsu, Kasumigaura, Kyoto and Toyonaka Cities, were recognized as a citizenled partnership with local administration that had determined the content or direction of Local Agenda 21 programs. ${ }^{49}$ It was also found that only Osaka prefecture had reviewed and altered its Local Agenda 21 program every fiscal year while 72 percent of Local Agenda 21 programs at the prefectural level and 58 percent at the municipal level were equipped with a program review mechanism. ${ }^{50}$ Overall, the state of Local Agenda 21 adoption in Japan still has a long way to go before achieving a participatory process of continual policy formation.

\section{Climate Change Action}

Article 4 of the 1998 Climate Change Law states: "Local governments shall promote policies to limit greenhouse gas emissions in accordance with the natural and social conditions of their areas." This gives statutory recognition to the advantages of decentralization, emphasizing that the nature of environmental problems is often location-specific and can be managed at different geographical areas. A significant number of Japanese local governments have accordingly been implementing their action plans for emission reductions in their geographical areas; as of December 2007, 100 percent (47) of 47 prefectures, 82 percent (14) of 17 designated cities, and 33 percent (562) of 1,686 small and medium-sized municipalities had drawn up such plans. ${ }^{51}$ It was found that almost all of these plans included emission reduction targets and designated reduction measures but only a very few

47 Kanagawa Kōji, "Jichitai Keikaku to Pātonashippu Kankei ni okeru Rōkaruagenda 21 no Ichizuke" [Positioning Local Agenda 21s in the local planning structure and partnership relations], Toshi Kenkyū [Urban Studies] 4 (2004): 43-50.

48 Ministry of the Environment, "Rōkaruagenda 21 no Sakutei Jōkyōtou Chōsa Kekka nit suite."

49 Kawasaki Kenji, "Shimin to Gyōsei no Pātonāshippu ni yoru Jichitai Kankyō Manējimento" [Local environmental management by a partnership between citizens and administration ], Chiiki Kaihatsu [Regional Development], 426 (March 2000): 54-62; Japan ICLEI, "Nihon no Jichitai no Ajenda 21 Jisshi Jōkyō Chōsa Hōkoku” [Report on the state of practice of Japanese local government's Agenda 21], May 2001.

50 Ministry of the Environment, Press Release, 13 May 2003.

51 Ministry of the Environment, Chihō Kōkyō Dantai ni okeru Chikyū Ondanka Taisaku no Suishin ni Kansuru Hōritsu Shikkō Jōkyō Chōsa Kekka. Article 20-3 (2008 amendment to the Climate Change Law) obligates prefectures and designated, core and special cities to formulate measures to reduce $\mathrm{CO} 2$ emissions from business activities and households in their areas. 
plans clearly articulated locally specific measures that were credible or achievable for emission reduction targets. ${ }^{52}$

In December 2004, Kyoto City enacted the Kyoto City Global Warming Countermeasures Ordinance to reduce GHG emissions to 10 percent below 1990 levels by 2010, becoming the first local government in Japan to put such a specialized ordinance into effect. Five prefectures (Kyoto and Osaka in 2005, Nagano in 2006, Wakayama and Shizuoka in 2007) and two municipalities (Kawagoe in 2007 and Chiyoda Ward in 2008) followed suit and Kawasaki, Kitakyushu and Yokohama Cities plan to enact such ordinances. The ordinance-based countermeasures have been taken partly by the recognition that the energy consumption of the Japanese households has grown much faster than the industrial sector ${ }^{53}$ and changes in lifestyle and social beliefs are thus crucial to the success of effective GHG emissions reduction. The success of such changes requires greater collaboration between local administration and citizens for information sharing that ensures a better informed citizenry and publicly monitored administrative decisions. As of 2010, 42 percent of 1,358 local governments had been practicing some forms of collaboration with citizens for emission reduction countermeasures, yet only 10 percent of these collaborative schemes had been initiated or requested by their local residents. ${ }^{54}$ In other words, a large majority of collaborations had been led by local administration.

Stakeholder meetings for the introduction of Tokyo's cap and trade system are regarded as one such administration-led collaboration. At the 2007 meetings, the Tokyo metropolitan government successfully sought ex-postfacto approval of administrative initiatives from business establishments, environmental NGOs and academics. ${ }^{55}$ Since the administration-led system, targeted for mandatory emission reductions among big emitters, was well prepared and well documented, the Tokyo Chamber of Commerce, along with the general public, came to fully support the cap and trade system in $2008 .{ }^{56}$ Kyoto City is another active locality yet with a citizen-led, rather than administration-led, approach to collaboration. Its Miyako Agenda 21 Forum (as of 2008, consisting of 551 members, made up of citizens' groups, academics and business associations), which works in collaboration with local

52 Ministry of the Environment, Chihō Kōkyō Dantai ni okeru Chikyū Ondanka Taisaku no Suishin ni Kansuru Hōritsu Shikkō Jōkyō Chōsa Kekka, 57-58; Wada and Taura, Shimin Chiiki ga Susumeru Chikyū Ondanka Bōshi, 32-33.

53 Ministry of Economy, Trade and Industry, Enerugī Hakusho [White paper of energy], 2010 ed., chapters 1-1-2; available from http:/ / www.enecho.meti.go.jp/topics/hakusho/2010energyhtml/, last accessed 3 November 2011.

54 See Ministry of the Environment, "Kankyō Kihon Keikaku ni Kakawaru Chihō Kōkyō Dantai Ankēto Chōsa," 62, 70.

55 Tokyo Metropolitan Government, "Sutēkihorudā Mītingu" [Stakeholder Meetings]; available from http:/ / www2.kankyo.metro.tokyo.jp/kikaku/kikouhendouhousin/index.htm, last accessed 21 May 2010.

56 Chiba, Interview by author, 20 May 2010, Tokyo; Okamoto Naomi (Tokyo Metropolitan Section Chief of Emissions Reduction Countermeasures), interview by author, 23 June 2011. 
administration, has promoted action plans towards achieving a low carbon city and has engaged in a range of educational promotions for raising public awareness. ${ }^{57}$

\section{Environmental Impact Assessments (EIA)}

Long before the 1997 enactment of the national Environmental Impact Assessment Law (EIA law), some local governments had already implemented relatively comprehensive assessments, responding to public pressure to take preventive measures rather than ex-post countermeasures against industrial pollution. ${ }^{58}$ Kawasaki City was the first local government in Japan to enact an Environmental Impact Assessment Ordinance in 1976 while both the Tokyo Metropolitan government and Kanagawa prefecture followed suit in 1980. As of April 2010, all major localities (47 prefectures and 15 designated cities) enacted their EIA ordinances under the direction of the national EIA law. ${ }^{59}$ The objective of local EIA was to carry it out "within the law" but to also apply it more flexibly than the national law designated, in order to cover smaller and more diverse projects for meeting local needs.

All local EIA procedures have independent review commissions (shinsakai), which act as advisory assessors to provide technical/expert opinions at various stages of EIA. Most local EIA ordinances also stipulate an administrative obligation for public hearings ( $k \bar{o} c h \bar{o} k a i)$ that local chief executives consider necessary to hold at any stage. Equally important, EIA brings citizen participation to a new dimension. In the area of industrial pollution, the third party (the general public) had not been specifically stipulated in Japan's legal system and thus normally could not act as a formal participant, yet EIA has provided a new way of opening up the scope of participation to the general public. In fact, most local EIA procedures define participants as "those who have opinions from the standpoint of protecting the environment" (no geographically defined limits) ${ }^{60}$ Nonetheless, there is a major problem commonly found in these local EIA systems; consultation at an early stage of projects does not normally fall within the scope of EIA, and thus the public finds it impossible to consider alternatives to the proposed projects. As of 2004, three prefectures (Tokyo, Hokkaido and Hyogo) and one municipality (Zushi) had an institutionalized system of citizen participation explicitly

\footnotetext{
57 Kitagawa, interview by author, 13 May 2010, Kyoto; Imai, Interview by author, 18 May 2010, Kyoto.

58 Tanaka Mitsuru and Okiyama Fumitoshi, "Chihō Kōkyō Dantai ni okeru Kankyō Asesumento Sēdo no Rekishi kara no Kyōkun" [Lessons on the history of environmental impact assessment by Japanese local governments], Asesumento Gakkaishi [Journal of Environmental Impact Assessment] 8, no. 2 (August 2010): 6-16.

59 Ministry of the Environment, Environmental Impact Assessment Network; available from http:// www.env.go.jp/policy/assess/6-1system/index.html, last accessed 3 November 2011.

${ }^{60}$ Yanagi Ken'ichirō, "Chihō Jichitai Asesu Jōrei no Saikin no Dōkō Bunseki" [A recent trend analysis of local government Assessment Ordinances], NIRA Policy Research 13, no. 12 (December 2000): 36-39.
} 
prescribed in their EIA ordinances, and three prefectures (Tokyo, Saitama and Mie) and two municipalities (Kyoto and Kawasaki) had an EIA mechanism for early draft plans, which was embedded in their EIA ordinances. ${ }^{61}$ The only exception is the Tokyo metropolitan government, which, to ensure public consultation at an early stage, uses its EIA as a planning tool when projects are conceived and planned and to assess them for integrating environmental, social and economic considerations in decision making.

\section{Officials' attentiveness}

In Japan, the capacity of local assemblies to keep their chief executives in check has been seriously constrained by the phenomenon of òru yotōka (all parties ruling together without political opposition).$^{62}$ As a result, incentives for local officials' attentiveness are largely institutionalized in their executive branches, providing a way of reaching out to citizens in a direct way. The effectiveness of local government's attentiveness to what the people think significantly derives from local administration. Under the presidential system, Japanese local governments have directly elected mayors or governors. These chief executives have greater control over an entire government personnel and organization than the prime minister does at the national level. In general, local authorities, the layer of government closest to the people, are under constant pressure to quickly respond to popular demands. In the field of local environmental policy in Japan, there are two areas of development for incentive structures to officials' attentiveness: environmental performance disclosure and environmental policy coordination.

\section{Environmental Performance Disclosure}

In general, sub-national government ensures better information disclosure than national government does. Local governments are not distracted by the secrecy needed in "high politics." The number of local government disclosure ordinances rose rapidly from 56 in 1985 to 178 in 1990; as of April $2009,99.7$ percent $(1,842)$ of all local governments in Japan were providing disclosure at some level. ${ }^{63}$ The information release ratio by the Tokyo Metropolitan government between 2000 and 2004, for example, was 97 percent of 13,402 disclosure requests. ${ }^{64}$ Indeed, the information disclosure

${ }_{61}$ Ministry of the Environment, "Senryakuteki Kankyō Eikyō Hyōka ni tsuite" [Strategic Environmental Assessment]; available from http://www.env.go.jp/council/02policy/y0210-04/mat06. pdf, last accessed 3 December 2009.

62 In 2010 over 99 percent of mayoral proposals sailed through local assemblies almost intact. See National Association of Chairpersons of City Councils, "Shichō Tēshutsu ni yoru Gian" [Mayorproposed agenda items]; available from http://www.si-gichokai.jp/official/research/jittai22/ pdf/08_jittai22.pdf, last accessed 3 November 2011.

63 Ministry of Internal Affairs and Communications, Press Release, 7 August 2009.

64 Release Ratio $=($ Release + Partial Release $) /($ Cases Claimed - No Existence of Information $)$. Data provided by Policy Information Office, Tokyo metropolitan government. 
of government performance has become a common practice among prefectures and major cities; those authorities introducing a government performance appraisal system increased markedly from 18.1 percent of all local governments in 2004 to 54.4 percent in 2010 (98 percent of 47 prefectures and 95 percent of 18 designated cities). ${ }^{65}$ It should be noted that there are no legal obligations for local authorities either to introduce such a system or to comply with a nationally defined way of evaluation when they decide to introduce. Performance evaluation is generally carried out by their administrative organizations (self-evaluation) and primarily focuses on a post-facto examination of project outcomes. Yet there is some evidence that the number of local governments implementing their evaluation at the policy level as well as at the program level is on the increase: 39 percent of prefectures and 22 percent of designated cities. ${ }^{66}$ In this context, the use of both the specific policy level and ante-facto evaluation for EIA, as described previously, is likely to provide a greater incentive to local officials' attentiveness.

\section{Environmental Policy Coordination}

In Japan, environment and pollution control agreements (EPCAs) with specific enterprises have been an effective measure of local environmental policy to regulate major "point source polluters." In 1993 there were 42,000 such agreements between local authorities and individual enterprises ${ }^{67}$ Yet there had been a lack of implementation transparency in EPCAs. As the scope of local environmental policies expanded beyond industrial pollution control, the enactment of local ordinances was necessary in order to clarify on what legal grounds local authorities could exercise their power over diffuse, "nopoint sources" of pressures on the environment. In the early 1990s, as the objectives of Japan' environmental policy moved away from one-dimensional pollution control toward a sustainable society and environment, the scope of regulatory objects was to expand from business activities through city planning to consumer behaviour. The expansion of policy scope necessitated policy coordination between environmental and other departments and required expertise for a diverse set of administrative tools.

When responsibilities overlap, conflict may result. Inter-departmental coordination is thus required. There have been more examples of institutionalization for "comprehensive environmental policy-making." One such example is the creation of a Global Warming Countermeasures Promotion Office, which is expected to draw up large-scale GHG emissions reduction plans, to be implemented on a top-down basis. This office is usually attached to the chief executives' office for policy coordination. As of 2009,

65 Ministry of Internal Affairs and Communications, Press Release, 16 March 2011.

66 Ministry of Internal Affairs and Communications, Press Release, 16 March 2011.

67 Ministry of the Environment, Chihō Kōkyō Dantai no Kankyō Hozen Taisaku Chōsa [Investigation on the environmental conservation measures of local governments] (Tokyo: MOE, 2005). 
eight prefectures and six designated cities operated such headquarters for climate change policy. ${ }^{68}$ Some local governments recognize that jinji-ido (organization-wide job rotation practice), which is carried out every year before the new fiscal year starts in April, would disrupt policy continuity and prevent employees from developing their expertise. To overcome the adverse effects of personnel reshuffle, in 2009 Kyoto City created a new job classification, kankyō-shoku (environmental specialists) for managing environmental issues ${ }^{69}$ Informally, the Tokyo metropolitan government has been giving a priority to employees' preferences for personnel reshuffle. As a result, there has been a substantial increase in the number of experienced environmental specialists. ${ }^{70}$

\section{Governmental Performance}

\section{Officials' efficiency}

It appears that chief executives of localities with a larger population (or larger tax base) tend to see themselves as administratively more able to exercise their discretion in carrying out responsibilities. According to a survey of local chief executives' perceptions (allowing only yes or no responses), 49.6 percent of 1,905 respondents saw local government as lacking the competency to carry out the responsibilities demanded by decentralization. The percentages of prefectures (100 percent) and cities (70.2 percent) claiming to be competent, as compared with towns and villages (39.1 percent), were large enough to call this finding into question. ${ }^{71}$

\section{Political Leadership}

A large majority of Japanese local authorities have displayed copycatting behaviour (yokonarabi) in regards to climate change policy by implementing nationally subsidized policy measures or following nationally defined policy measures that neighbouring localities have adopted. Under these circumstances, a number of case studies have come to the conclusion that political leadership—usually mayoral or gubernatorial leadership—is a key ingredient in a local government's ability to introduce progressive low carbon measures. ${ }^{72}$ It was reported that, without some form of commitment from

68 Local Green Government Portal, Local Green Government Portal; available from http://www. climate-lg.jp/policy/gw-city.html, last accessed 14 December 2009.

${ }_{69}$ In Japan, positions for local government employees are typically classified into two categories: ippan-shoku (generalists) and gijutsu-shoku (technical employees). Kyoto City was the first municipality to create such a classification for policy continuity and expertise accumulation.

70 Chiba, Interview by author, 20 May 2010, Tokyo.

$71 \quad$ Sankei Shinbun, 8 January 1996, carried a report on the survey of 1,905 chief executives (57.7 percent of all local chief executives) in Japan.

72 See, for example, Itakura Toshimasa, "Shimin Sanka ni yoru Kankyō Jōrei Zukuri” [Making an environmental ordinance through citizen participation], Keikaku Gyōsei [Planning Administration] 
the chief executive, progressive proposals may never get onto a policy agenda despite being initially presented by an informal policy network of those (government officials, NGOs and academics) interested in low carbon issues. ${ }^{73}$ At the stage of policy formation, however, the exercise of the chief executive's power may not promote but rather undermine the policy rationale if it is politicized to the extent to which there exist tensions between the chief executives and local assemblies or influential local figures (as seen when Tokyo Governor Ishihara strained relations with big business over his intention to introduce Tokyo's cap-and-trade in 2002-2007) ${ }^{74}$ From the viewpoint of local administration, the department concerned is less likely to commit itself to progressive policy making if there are such tensions or there is a high likelihood of changing hands to a new chief executive (as when Nagano Governor Tanaka failed to win the goodwill of his government officials for cooperation in 2002-2006) ${ }^{75}$ To make these recalcitrant actors commit to or support progressive low carbon measures, the ideal chief executive would require sufficient financial resources and political opportunities to be exploited by political leadership (as Ishihara's bid for the 2016 Olympic Games, under the slogan, "Carbon Minus Olympics," legitimized stringent mitigation measures in 2006). ${ }^{76}$

\section{Administrative Ability}

As of April 2004, the total number of local government employees in environmental administration stood at 14,518 (8,252 for pollution and 6,266 for environmental conservation). Within the context of administrative reforms, the overall size of local administration in terms of employment had decreased by nearly 10 percent between 1993 and 2004; in contrast, the number of local government employees in environmental conservation increased rapidly by 52 percent during the same period. In every prefecture and designated city, along with a bureau for environmental administration (177 employees on the prefectural average and 198 employees on the designated-city average), multiple sections were established within this environmental bureau. As far as other municipalities were concerned, only

24, no. 3 (September 2001); 78; Baba Kenshi, Aoki Kazumasu and Kimura Osamu, "Analysis of Environmental and Energy Policy Processes in Local Governments in Japan,” Denryoku Chūo Kenkyūjo Hōkoku [Central Research Institute of Electric Power Industry Report] Socio-economic Research Center, Rep. No. Y05025 (May 2006): ii; Fujii Yasuhira, “Tokubetsuku ni okeru Kankyō Kihon Jōrei no Seitei Katei Bunsei" [Analysis of basic environmental ordinance-making processes in Special Wards], Sōkan Shakai Kagaku [Relative Social Sciences] 17 (2007): 76.

73 Aoki Kazumasu, "Senkuteki na Jichitai Ondanka Bōshi Seisaku no Seihi o Meguru Seisaku Katei Bunseki" [Policy analysis of progressive preventive-measures for climate change by local governments], Tomidai Keizai Ronshu [Economic Journal of Toyama University] 56, no. 2 (November 2010): 136-39.

${ }_{74}$ Chiba, Interview by author, 20 May 2010, Tokyo; Okamoto, Interview by author, 23 June 2011.

75 Aoki, "Senkuteki na Jichitai Ondanka Bōshi Seisaku no Seihi o Meguru Seisaku Katei Bunseki," 144-47.

76 Chiba, Interview by author, 20 May 2010. 
13 percent (233 municipalities) had an independent department of environmental administration. In nearly 90 percent of municipalities with populations of less than 10,000, and in about 66 percent of municipalities with populations of more than 10,000 but less than 30,000, there was no specialist responsible for environmental administration. ${ }^{77}$

In 1998 Shiroi Town in Chiba prefecture was the first local government in Japan to acquire the ISO 14001 (international environmental management standards) certificate, in order to take initiatives in promoting projects that would reduce the burden on the environment. The number of ISO 14001 accredited local governments grew rapidly, peaking at 513 localities in 2004 and declined to 269 localities in 2009. This decline was due primarily to an amalgamation of localities but also to the introduction of new standards of EMS (environmental management system), such as LAS-E (Local Authority's Standards in the Environment). As ISO 14001 had been initially used for manufacturing facilities, by 200832 percent of ISO 14001 accredited local governments declared they were going to adapt ISO 14001 as their own. ${ }^{78}$ As of January 2008, 37 percent of local governments were performing under some form of EMS and 22 percent of these had developed their own EMS systems. ${ }^{79}$

In a broad sense, performance evaluation for local climate adaptation needs to focus not only on the evaluation of individual projects, but also that of policy making and policy implementation as a whole. As of October 2010, 54 percent of Japanese local governments (977) — 98 percent of prefectures, 95 percent of designated cities, 78 percent of other cities, and 30 percent of towns/villages-have introduced a system of administrative evaluation. ${ }^{80} \mathrm{Yet}$ a Mitsubishi Research Institute survey, conducted in 2009, indicates that only 9 percent of 490 cities have incorporated policy evaluation as part of their administrative evaluation while 34 percent of these cities have adopted implementation evaluation and 70 percent have conducted project evaluation (on a case-by-case basis) within their administrative evaluation. ${ }^{81}$

\section{Financial Capacity}

Massive budget deficits have remained in most Japanese local governments as their spending has far exceeded revenues. Since the early 1990s, their

77 The figures in this section is based on a report, "Chihō Kōkyō Dantai no Jōkyō ni tsuite" [The situation of local governments], provided on 17 March 2005 at a General Policy Meeting of the Central Environment Council.

78 The figures of ISO 14001 are provided by the Japan Accreditation Board.

79 The figures are based on a survey on environmental management, conducted by the Knowledge Management Research \& Institute in January 2008, with 685 respondents of local governments.

${ }^{80}$ Ministry of Internal Affairs and Communications, "Chihō Kōkyō Dantai ni okeru Gyōsei Hyōka no Torikumi Jōkyō" [The state of administrative evaluation by local governments], Press Release, 16 March 2011.

81 In August-September 2009, Mitsubishi Research Institute conducted a survey on administrative evaluation, with 845 respondents of local governments. 
budget deficits and outstanding debt have increased significantly. Existing local borrowing as a percentage of GDP rose rapidly from 15.5 percent in 1991 (when the bubble economy burst) to 38.1 percent in 2007. In fiscal year 2005, 27.5 percent $(514)$ out of all local governments $(1,874)$ showed more than 18 percent of borrowing burden ratio (debt service / total value of ordinary financial resources). Only Tokyo Metropolis seemed to stand out in this fiscal crisis with US\$2,450 in fiscal year 2005 of its per capita local tax revenue amounting to roughly twice the level of the prefectural average. ${ }^{82}$ In this respect, there is a potential for financially weak local authorities to move towards lax emissions control standards (or fiscal crisis as an incentive to be a free rider on the environmental protection effort of others) in order to increase their tax base.

Some areas of climate policy such as economic incentives require a significant degree of fiscal autonomy and capacity at the local government level. By December 2007, 238 municipal programs were reported to offer subsidies, funding and/or tax incentives for the promotion of energy efficiency and new energy ${ }^{83}$ So far the Tokyo metropolitan government is the only local government in Japan that is able to implement a package of these measures as a comprehensive system of environmental policies. In 2009 it started its own tax system to promote energy saving for small-and-mediumsized companies ${ }^{84}$ Its fiscal elasticity significantly affects the scope of Tokyo metropolitan initiatives. The Tokyo metropolitan government has a great deal of freedom for budgetary choice, which allows it to offer a more comprehensive incentive program for climate change adaptation, though it is constrained by nationally defined revenue-raising regulations like any other local government.

\section{Fairness of government outputs}

To assure greater fairness, projects need to be assessed at the early stage of problem identification and throughout the planning and decision-making processes. In Japan, only a few local authorities, such as Kobe and Kawasaki Cities, have carried out a comprehensive process of evaluating the environmental impact of policies, plans or individual projects and their alternatives at earlier stages. Probably the most advanced process is found in a new practice of the Tokyo metropolitan EIA, which was revised in 2002. Under this EIA, the Tokyo metropolitan government has assessed the environmental impact of projects at earlier stages and responded to the cumulative, compound environmental impact in greater-area development

82 Ministry of Internal Affairs and Communications, Local Public Finance in Japan; available from http://www.soumu.go.jp/english/pdf/lpfij.pdf, last accessed 14 December 2009.

\footnotetext{
${ }^{83}$ Ministry of the Environment, Chi Kansuru Hōritsu Shikkō Jōkyō Chōsa Kekka.
Kansu

${ }^{84}$ Tokyo Metropolitan Government, Hōdō Happyō Shiryō [Press Release Material] 31 March 2009.
} 
plans. ${ }^{85}$ But it is important to note that such progressive measures are confined to a small minority of front-runner localities in Japan.

Citizen participation is a key determinant in fostering fairness of the policy process. A number of case studies on Japanese localities do point to two driving forces for promoting environmental equity: socially mobilized citizens and mayoral/gubernatorial leadership. ${ }^{86}$ Using the frameworks of political opportunity structures ${ }^{87}$ it can be argued that the enabling institutional environment for a greater degree of participation provides citizens with access to a local government's capacity to enhance environmental equity. The formal institutional access, which provides incentives for civil society participation to thrive in fair decision making, ranges from the legaladministrative institution of central-local relations, electoral systems, to party systems and political alliances. However, those case studies illustrate that the opportunity structure for direct forms of citizen participation, which appears to be either empowered or constrained by demographics, played a primary role in promoting environmental equity. Although a lack of case studies makes my observation only suggestive rather than definitive, there seems to be a threshold size, probably exceeded only in the multi-million population cities, at which the greater number of organizations and the more complex decision-making processes come to outweigh the political efficacy of direct forms of citizen involvement. Equally important, no reports on the smaller size categories of fewer than 30,000 people (as of 2011, 869 out of 1746 municipalities) are found in those case studies. I would expect less political actors involved in small villages that are less complex and reveal less diversity. Within this limit, the smallness of local governments is likely to nurture political participation by virtue of their accessibility and intimacy.

The direct forms of citizen involvement for promoting overall fairness can be categorized into three basic patterns: doing citizens' planning on their own with the help of relatively neutral municipal authorities (Hino City's Basic Environmental Plan in 1999, with a population of 170,000, Toyonaka City's Agenda 21 in 1999 with a population of 390,000); citizens' planning collaboration on equal terms with local administration (Hikone City's Basic Environmental, and Action Plans in 2001 with a population of 110,000 and Shiki City's Basic Environmental Plan and Eco City in 1999 with

\footnotetext{
85 Tokyo Metropolitan Government, Environmental Impact Assessment System of the Tokyo Metropolitan Government (Tokyo: TMG, 2006).

86 See, for example, Itakura, "Shimin Sanka ni yoru Kankyō Jōrei Zukuri," 73-78; Fujii, "Tokubetsuku ni okeru Kankyō Kihon Jōrei no Seitei Katei Bunsei," 71-77 Hiraoka and Wada, "Chihō Jichitai ni okeru Shiminsankagata no Chikyū Ondanka Taisaku o Suishinsuru Shikumi to Shakaiteki Haikei," 47-53.

87 Sidney Tarrow, Struggle, Politics, and Reform: Collective Action, Social Movements, and Cycles of Protest (Ithaca, NY: Cornell University Centre for International Studies, 1991); Hanspeter Kriesi, "The Political Opportunity Structure of New Social Movements: its Impact on their Mobilization," in The Politics of Social Protest, eds. J. Craig Jenkins and Bert Klandermans (Minneapolis: University of Minnesota Press, 1995), 167-98.
} 
a population of 65,000); citizens' agenda setting and local administration's planning (Date City's Basic Environmental Plan in 1999 with a population of 35,000 and Ichikawa City's Basic Environmental Plan in 2000 with a population of 450,000$).^{88}$

\section{Conclusion}

Since the early 1990s, the focus of Japan's environmental policy has shifted from one-dimensional industrial pollution control to a comprehensive environmental governance strategy. Local officials have limited capacity to handle diffuse pressures on the environment, which requires their accountability mechanisms as well as their accumulated expertise and encouragement of citizens' political involvement. The international agreement made by Japan to reduce GHG emissions puts pressure on local authorities to take initiatives for climate adaptation. Most Japanese localities have yet to take policy initiatives in response to such pressure.

This study concludes that in Japan, with regard to the government's competence/efficiency, only the largest municipalities and prefectures possess a substantial degree of expertise and resources that they can use to reduce urban energy intensity and $\mathrm{CO}_{2}$ emissions. Depending on their local capacity for political leadership, administrative ability and financial discretion, some forward-looking localities have been ushering in a new level of development for operating innovative environmental programs. Probably the most exceptional case is the Tokyo metropolitan government, whose strong independent sources of revenue allow for a comprehensive system of climate policy including the 2010 introduction of its cap-and-trade system.

Yet efficiency and equity are seen as trade-offs against each other. In large localities, the size of the population appears to be too large and diverse to facilitate direct forms of participation for ensuring the fairness of the government's outputs. Instead, the large localities tend to address the issue of policy process fairness, such as EIA, at earlier stages. It is only in pioneering medium-sized municipalities that mobilized citizen groups demonstrate some success in holding governmental procedures accountable and responsive to their communities in a direct way. Direct participation itself becomes a process of spontaneous learning, a means for citizens to gain significant subjective political competence and to develop quasi-professional expertise on climate change.

Curtin University, Perth, Australia, August 2012

${ }^{8}$ Kawasaki, "Shimin to Gyōsei no Pātonāshippu ni yoru Jichitai Kankyō Manējimento," 56-61; Takahashi, "Jichitai Kankyō Kihon Keikaku no Genjō to Kadai," 19-34. 